\title{
The effects of feeding graded levels of microbially fermented cassava tuber wastes (CTWs) on blood viscosity and bone quality of finisher cockerels.
}

Aro, S.O.

Department of Animal Production and Health, Federal University of Technology, Akure, Nigeria.

\begin{abstract}
$\overline{\text { Two cassava tuber wastes (CTWS), namely cassava peels (CAP) and cassava starch residues }}$ (CSR) were subjected to solid substrate fermentation using a combination of microorganisms (Lactobacillus delbrueckii, Lactobacillus coryneformis and Aspergillus fumigatus), in order to improve their nutritive quality and reduce their levels of anti-nutrients. The microbially fermented products from the two wastes: microbially fermented cassava peels and microbially fermented cassava starch residues (MFCP and MFCSR) were thereafter used at varying levels to formulate seven standard cockerel diets designated as Diet 1 ( $0 \%$ CTWS), Diet 2 (20\% MFCP), Diet $3(40 \%$ MFCP), Diet 4 (60\% MFCP), Diet 5 (20\% MFCSR), Diet 6 (40\% MFCSR) and Diet 7 (60\% MFCSR). Two hundred and ten day-old cockerel chicks were randomly allotted to the seven treatment diets. The chicks were fed with these diets for seventeen weeks. Forty two birds were selected at the end of the seventeenth week of the experiment and were slaughtered. Bone quality and blood viscosity of the cockerel birds were used as response criteria. The result showed that the whole blood viscosity was statistically similar while plasma viscosity was influenced significantly $(P<0.05)$ by the dietary treatments. Whole blood viscosity ranged from 2.36 centistokes in $60 \%$ MFCSR diet to 2.82 centistokes in the 20\% MFCP diet. Blood viscosity decreased with increasing levels of CTWs in the diets. Flesh to bone ratio of the femur decreased correspondingly with dietary levels of the fermented wastes except in 40\% MFCSR while percentage bone moisture increased as the level of inclusion of the wastes increased in the diets. $40 \% \mathrm{MFCP}$ had the highest percentage bone ash (33.83\%) while 20\% MFCSR had the highest value for volumetric bone density $(1.15 \mathrm{~g} / \mathrm{ml})$ while birds fed the $20 \% \mathrm{MFCP}$ diet had the least value for bone ash percentage (27.12\%) and bone ash concentration. Since bone ash concentration, percentage bone ash and weight of bone ash in all the treatments did not vary significantly in comparison with the control except in 20\% MFCP, it could be concluded that the utilization of these wastes even at $60 \%$ level would not compromise the bone quality parameters of cockerel birds. This experiment also showed that cassava tuber wastes could decrease both plasma and whole blood viscosity and significantly so if plasma viscosity is taken into consideration. The lower viscosity of birds fed CTW with higher inclusion is suggestive of a positive influence of the CTW diets on the mechanical and geometric properties of the red blood cells.
\end{abstract}

Keywords: Bone quality, cassava tuber wastes, cockerels, fermentation, viscosity 


\section{Introduction}

Among the poultry birds, the broilers and turkeys are considered as the meat type birds, the layers as the egg machines while their male counterparts : the cockerels are regarded as hatchery wastes at the point of hatching in the developed countries and are hence recycled as livestock feed components. However, there are emerging potentials for the cockerel birds in developing countries as meat-type birds especially when reared beyond sixteen weeks of age to target the festive periods like the Christmas and the Easter seasons. Consumers have reported cockerel meat to be firmer in consistency, tastier and less fatty than that of broilers. It is also relatively cheaper to raise cockerels to $2 \mathrm{~kg}$ body weight than broilers because of lower cost of feed and medication and the hardiness of the cockerel birds. Harnessing these inherent potentials in cockerel production will therefore go a long way in ameliorating the shortage of proteins, particularly those of animal origin that is prevalent in most African countries reputed with low consumption of animal proteins (FAO, 1986).

High cost of inputs, most especially feeds limits the opportunity and the advantages of poultry production in Nigeria as feed has been reported to account for $60-70 \%$ of total production cost (Tewe et al., 1994). Energy and protein feedstuffs are more expensive and relatively scarce in comparison with other feedstuffs because they are in very high demand as staple food for humans (Faniyi and Ologhobo, 1999). The use of grains for feeding livestock when direct human needs have not been met raises economic and moral questions. To provide answers to these economic and moral questions, alternative feed sources for livestock that have no direct use for man like cassava peels, cassava starch residues and maize middling have been suggested (Aro et al., 2012). Also, limitations to the use of these agro-industrial by-products like their low crude protein and high fibre contents coupled with their high levels of feed anti-nutrients have been largely addressed by novel fermentation biotechnology using candidate microorganisms (Aro, 2010)

The effects of the utilization of agroindustrial products in ration formulation for livestock have been very varied and diverse. For instance Ani and Okorie (2009) reported that the use of castor oil bean meal (CBM) led to significant reductions in body weight, carcass yield, organ and relative organ weight as the level of CBM in the diets increased above $15 \%$. Oluremi et al. (2008) reported that fermentation of sweet orange (Citrus sinensis) peels did not result in disproportionate growth of most of the carcass cuts nor did it jeopardize the health of broiler birds. Health implications of feedstuffs on livestock can also be monitored from blood viscosity measurement - a somewhat neglected clinical screening especially in livestock husbandry. Research has shown that the visco-elasticity of blood and plasma of farm animals varies with their dietary supplements (Windberger et al., 1994).

Research efforts have also been concentrated on the effects of diets or dietary supplements on bone parameters like mineralization (Chan et al., 1976), bone breaking strength and bone ash (Park et al., 2003) and bone density (Potença et al., 2008; Shahnazari et al., 2009). All these research efforts revealed the impacts of feed dynamics on physiological parameters of bones with attendant benefits and constraints.

Attempt to investigate if such benefits and constraints could be advanced to cockerel birds fed with different dietary inclusion of 
microbially fermented cassava peel and cassava starch residue necessitated this study, especially if blood viscosity and bone quality of the birds were used as the response criteria.

\section{Materials and Methods}

\section{Experimental Site}

The experiment was carried out in the poultry unit of the Teaching and Research Farm (Livestock Section) of the Federal University of Technology, Akure, Ondo State, Nigeria. The farm is located in the humid rain forest zone of western Nigeria which is characterized by bimodal rainfall peaks and high humidity during the raining season. The mean annual rainfall is about $1,500 \mathrm{~mm}$ and the rain lasts for about 9 months usually from March to November every year. The mean annual relative humidity is over $75 \%$ and that of the temperature is about $27^{\circ} \mathrm{C}$.

Construction of the Fermentation Trays

The fermentation trays used for the study were made of ply-wood with the following dimensions; Length, $54 \mathrm{~cm}$, Breath, $39 \mathrm{~cm}$ and depth of $3.4 \mathrm{~cm}$. These trays were fitted inside plywood-built fermentation chambers in a six-tier arrangement (Figure I).

Preparations of the Feed Materials

Cassava peels (CP) and Cassava Starch Residue (CSR): The cassava peels were collected fresh from a gari processing community in Igbatoro area of Akure, Ondo state and were sun-dried for 5-7 days on a concrete slab depending on the sun

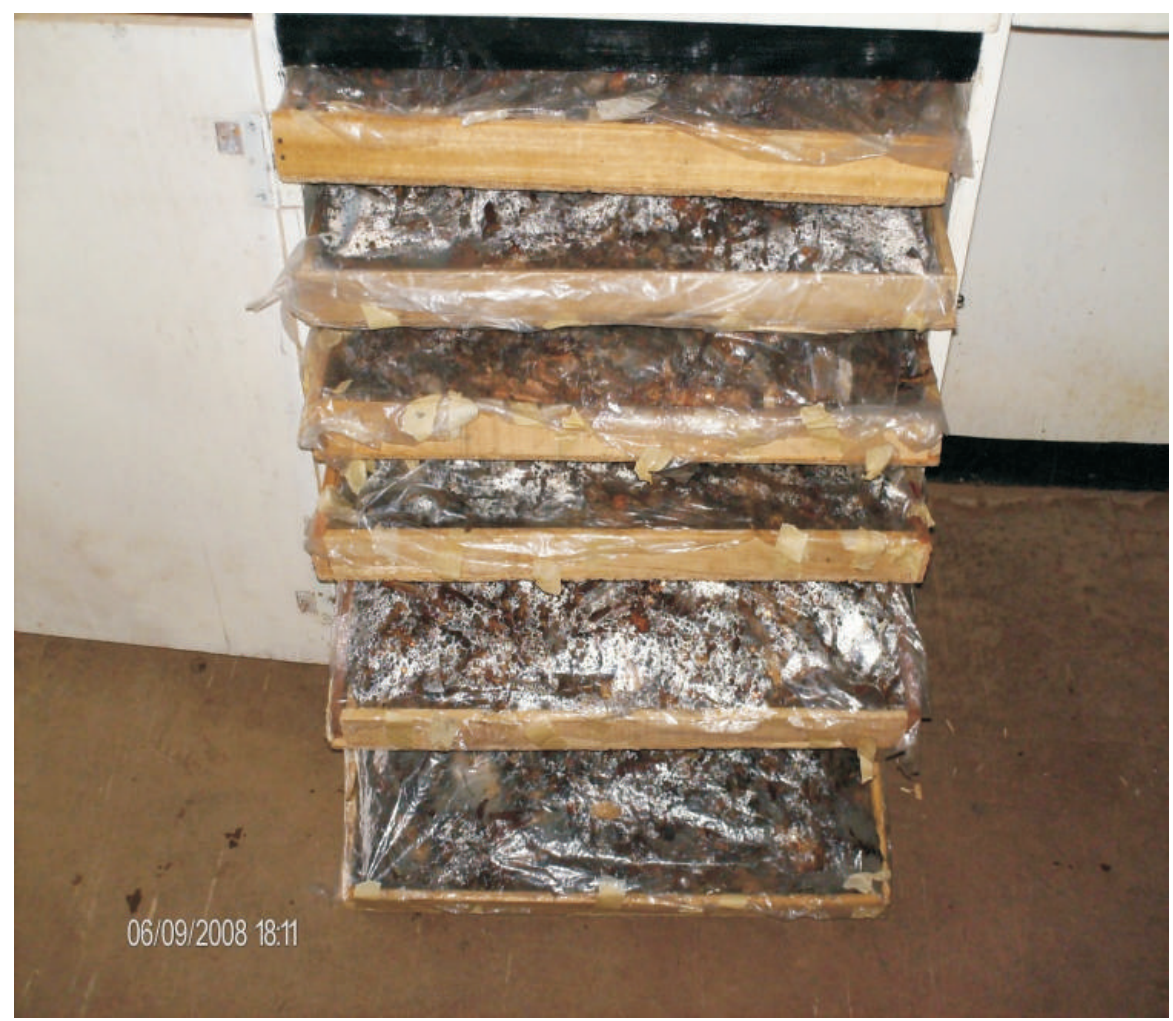

Figure I: Fermentation chamber with the 6 tier arrangement of fermentation trays. 


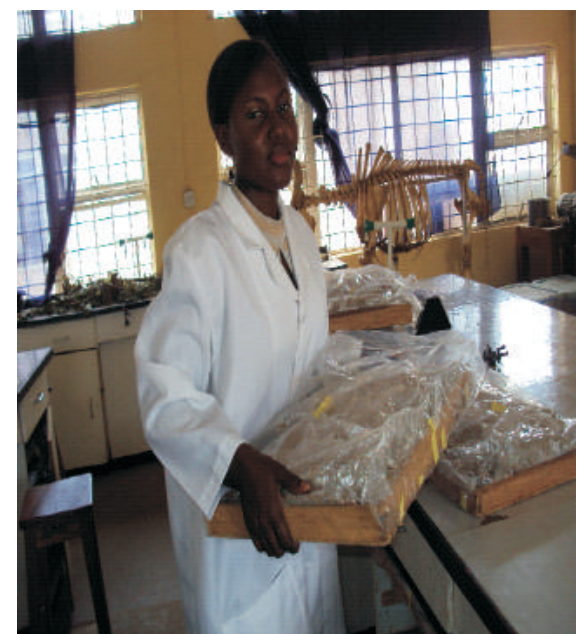

Figure II: Sealed fermentation tray

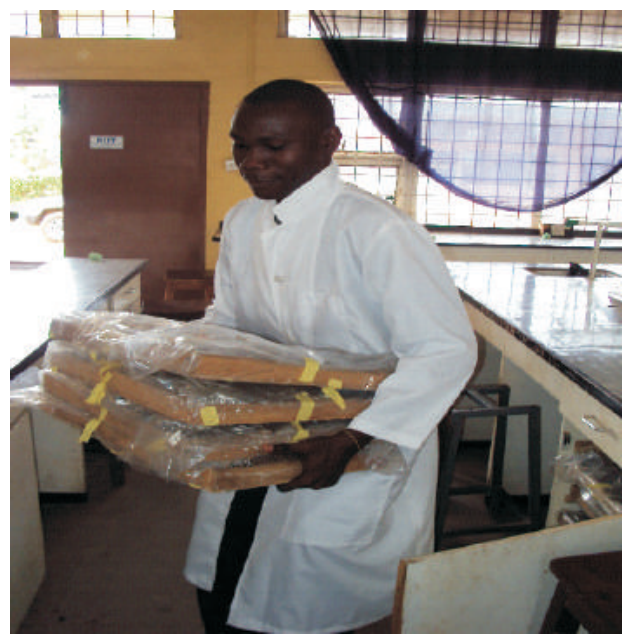

Figure III: Evacuation of trays after fermentation intensity. They were then packed in polythene sacks and transported to the feed mill of the Teaching and Research Farm (Livestock Section) of the Federal University of Technology, Akure (FUTA), where they were crushed to aid further processing, and later transported to FUTA's Department of Animal Production and Health laboratory, where they were stacked on a wooden platform prior to inoculation with fermenting microorganisms. Cassava starch residues were collected fresh from Matna Foods Limited in Ogbese, Ondo State, Nigeria. They were packed into sacks and pressed down to reduce the water content. The residues were then transferred to a slab where they were removed from the sack and sun-dried until the moisture content was reduced to the barest minimum. They were then packed in polythene sacks and transported to the feed mill of the Teaching and Research Farm (Livestock Section) of the Federal University of Technology, Akure (FUTA), where they were crushed to aid further processing, and later transported to the Department of
Animal Production and Health laboratory where they were stacked on a wooden platform until they were inoculated with fermenting microorganisms.

Preparation of Microbially Fermented Cassava Peel (MFCP) and Microbially Fermented Cassava Starch Residue (MFCSR)

Two kilograms $(2 \mathrm{~kg})$ of the crushed cassava peel (CAP) were weighed and mixed with $1,500 \mathrm{ml}$ of sterile water (ratio $1.33: 1 \mathrm{w} / \mathrm{v}$ ) and packed into waterproof cellophane bags and heat-sterilized in a cauldron containing boiling water for 30 minutes. After sterilization, the cassava peel was allowed to cool to about $37^{\circ} \mathrm{C}$ and then poured into already prepared trays which have been laid with transparent nylon in a laminar flow chamber. The sterilized cassava peel was then inoculated with $15 \mathrm{ml}$ each of pure culture of two lactic acid bacteria: Lactobacillus delbrueckii and Lactobacillus coryneformis each containing $1.03 \times 10^{4}$ cells $/ \mathrm{ml}$ and $30 \mathrm{ml}$ of a fungus; Aspergillus fumigatus containing 
$1.27 \times 10^{7}$ spores $/ \mathrm{ml}$ and properly mixed together. The inoculated samples were allowed to ferment in sealed fermentation trays (Figure II) for five days at room temperature and controlled relative humidity according to the method described by Aro (2010). The cassava starch residues (CSR) were similarly treated but with $2,000 \mathrm{ml}$ of sterile water in a 1:1 ratio $(\mathrm{w} / \mathrm{v})$. After the fifth day, the trays were brought out (Figure III) and the fermented cassava peels and residues were sun-dried for 3-5 days after which were then packed prior to their incorporation with other feed ingredients into standard cockerel diets.

Feed Formulation: Seven experimental diets were formulated according to NRC (1994) in which diet 1 which contained neither MFCSR nor MFCP served as the control diet, diet 2-4 contained $20 \%, 40 \%$ and $60 \%$ MFCP while diet $5-7$ contained $20 \%, 40 \%$ and $60 \%$ MFCSR respectively. Tables 1 and 2 show the gross composition of the cockerel starter and finisher diets respectively.

Experimental Animals and their Management: Two hundred and ten day-old cockerel birds were purchased for the experiment. The birds with an average initial weight of $37.95 \pm 0.37 \mathrm{~g}$ were allotted such that each treatment had 30 birds of 10 birds per replicate in a deep litter pen. The birds were fed their experimental diets and fresh clean water ad libitum daily throughout the feeding trial which lasted for a period of 17 weeks. The birds were placed under good hygienic conditions and necessary vaccines and prophylactic treatments were scheduled and administered as at when due. The birds were weighed per replicate once every week before feed and water were provided so as to minimize error due to gut fill.

Data Collection: Data were on bone quality parameters and on whole blood and plasma viscosities during slaughtering at the $17^{\text {th }}$ week of the experiment.

Slaughtering and determination of bone parameters: The birds were slaughtered at the seventeenth week of the experiment. Two birds were slaughtered per replicate given a total of six birds per treatment. The birds were weighed to determine their live weight. Feed was then withdrawn from them for 18 hours to empty their gut which helps to preserve the meat quality.

The birds were mechanically stunned before they were slaughtered.

Table 1: Gross Composition (\%) of cockerel starter Diets

\begin{tabular}{|c|c|c|c|c|c|c|c|}
\hline Ingredients & $0 \% \mathrm{CTW}$ & $20 \% \mathrm{MFCP}$ & $40 \% \mathrm{MFCP}$ & $60 \% \mathrm{MFCP}$ & $20 \% \mathrm{MFCSR}$ & $40 \% \mathrm{MFCSR}$ & $60 \% \mathrm{MFCSR}$ \\
\hline Maize & 52.00 & 37.75 & 22.75 & 0.00 & 36.00 & 20.00 & 0.00 \\
\hline Fish meal & 2.00 & 2.00 & 1.00 & 1.00 & 2.50 & 4.25 & 8.00 \\
\hline SBM & 10.00 & 10.00 & 8.50 & 0.00 & 0.00 & 0.00 & 0.00 \\
\hline GNC & 18.75 & 18.00 & 21.00 & 30.25 & 29.75 & 28.50 & 23.25 \\
\hline MFCP & 0.00 & 20.00 & 40.00 & 60.00 & 0.00 & 0.00 & 0.00 \\
\hline MFCSR & 0.00 & 0.00 & 0.00 & 0.00 & 20.00 & 40.00 & 60.00 \\
\hline PKC & 10.00 & 5.00 & 0.00 & 0.00 & 0.00 & 5.00 & 0.00 \\
\hline Veg. Oil & 2.50 & 2.50 & 2.00 & 4.00 & 2.00 & 2.50 & 4.00 \\
\hline Others & 4.75 & 4.75 & 4.75 & 4.75 & 4.75 & 4.75 & 4.75 \\
\hline Total (kg) & 100.00 & 100.00 & 100.00 & 100.00 & 100.00 & 100.00 & 100.00 \\
\hline $\mathrm{CP}$ & 20.41 & 20.38 & 20.39 & 20.49 & 20.08 & 20.13 & 20.31 \\
\hline M.E.(Kcal/kg) & 2710.92 & 2735.57 & 2737.92 & 2721.47 & 2712.72 & 2743.97 & 2703.92 \\
\hline
\end{tabular}


Effect of microbially fermented cassava tuber wastes on blood viscosity and bone quality of finisher cockerels

Table 2: Gross Composition (\%) of cockerel Finisher Diets

\begin{tabular}{llllllll}
\hline Ingredients & $0 \% \mathrm{CTW}$ & $20 \% \mathrm{MFCP}$ & $40 \% \mathrm{MFCP}$ & $60 \% \mathrm{MFCP}$ & $20 \% \mathrm{MFCSR}$ & $40 \% \mathrm{MFCSR}$ & $60 \% \mathrm{MFCSR}$ \\
\hline Maize & 62.00 & 46.75 & 32.00 & 17.00 & 45.50 & 29.00 & 18.00 \\
Fish meal & 1.00 & 1.00 & 1.00 & 1.00 & 1.00 & 1.00 & 8.75 \\
GNC & 19.25 & 18.75 & 18.00 & 17.25 & 21.50 & 23.50 & 8.75 \\
MFCP & 0.00 & 20.00 & 40.00 & 60.00 & 0.00 & 0.00 & 0.00 \\
MFCSR & 0.00 & 0.00 & 0.00 & 0.00 & 20.00 & 40.00 & 60.00 \\
PKC & 13.00 & 8.75 & 4.25 & 0.00 & 7.25 & 1.25 & 0.00 \\
Others & 4.75 & 4.75 & 4.75 & 4.75 & 4.75 & 4.75 & 4.75 \\
Total $(\mathrm{kg})$ & 100.00 & 100.00 & 100.00 & 100.00 & 100.00 & 100.00 & 100.00 \\
CP & 16.90 & 16.97 & 16.95 & 16.94 & 16.95 & 16.94 & 16.68 \\
M.E.(Kcal $/ \mathrm{kg})$ & 2566.12 & 2565.22 & 2573.87 & 2574.52 & 2567.57 & 2562.57 & 2512.37 \\
\hline
\end{tabular}

$\mathrm{GNC}=$ Groundnut Cake; SBM = Soya bean meal; MFCP = Microbially Fermented Cassava Peel; MFCSR $=$ Microbially Fermented Cassava Starch Residue; ME = Metabolizable Energy; CP = Crude Protein.

The Archimedes' principle (Zhang and Coon, 1997) was used to measure the density of the left thigh bone following post mortem harvest. The left thigh of each bird was removed and later cleansed of all soft tissues with a dissecting knife. The cleansed bones were weighed (W1), then air-dried for $12 \mathrm{hrs}$ at room temperature and later oven-dried at $105^{\circ} \mathrm{C}$ for $24 \mathrm{hrs}$. The ovendried bones were weighed (W2) to determine the moisture content (W2-W1), and were later crushed in the Animal Production and Health Nutrition Laboratory of the university. The crushed bones were carefully dropped inside a graduated cylinder filled with $200 \mathrm{ml}$ of water (V1); the new water level (V2) was recorded and subtracted from the initial volume to know the volume of the crushed bone immersed. These parameters were used in calculating the bone density which has it unit as $\mathrm{g} / \mathrm{ml}^{3}$. The bone density (Zhang and Coon, 1997) is given as: $\mathrm{W} 2 /(\mathrm{V} 2-\mathrm{V} 1)$.

Bone Ash Content and Organic Matter

To determine bone ash content, crushed bones were placed in a muffle furnace at $600^{\circ} \mathrm{C}$ for $6 \mathrm{hrs}$ according to the procedure of AOAC (1994). The percentage organic matter was determined relative to the ash content of the thigh bone. The \% Organic matter is given as: weight of bone $(\mathrm{g})$ minus weight of ash (g) x 100
Bone ash concentrations: Bone ash concentrations were calculated by dividing the ash weight of each bone by its volume determined using the Archimedes principle (Zhang and Coon, 1997).

Determination of whole blood and plasma viscosities

Forty two cockerel birds (six birds/treatments) were selected and fasted for a period of twelve hours to ensure gut clearance before being slaughtered, the birds were thereafter stunned, slaughtered and bled for blood collection via the jugular vein. Blood samples were collected into sample bottles with Ethylenediamine tetra acetic acid (EDTA) and the blood was agitated to avoid coagulation of the blood in the sample bottles. The values of the whole blood and plasma viscosity were calculated from the values obtained from the viscometer reading and the viscosities of both the whole blood and plasma were calculated using the formula below:

Viscosity

$=$ flow time of sample $\times 1.0038$

Flow time of water (Rosencranz and Bogen, 2006)

Where 1.0038 is the viscosity of water at standard temperature and pressure and the flow time of water is 55 seconds. 
Experimental design and statistical analysis: The experimental design was a completely randomized design and the data obtained were subjected to one-way analysis of variance. Difference between treatments means were separated using Duncan's multiple Range Test of SPSS Version 17 (2008) statistical package.

\section{Results and Discussion}

Table 3 shows the bone parameters of cockerels fed graded levels of microbially fermented cassava tuber waste based diets. The control had the highest value for the weight of the left thigh $(98.05 \pm 2.67 \mathrm{~g})$, bone dry matter percentage $(49.46 \pm 1.62 \%)$ and bone volume $(7.62 \pm 0.40 \mathrm{ml})$. Birds fed $20 \%$ MFCP had the highest value for the weight of left thigh bone $(16.17 \pm 0.40 \mathrm{~g})$ and percentage bone organic matter $(72.92 \pm 2.76 \%)$, birds fed $40 \%$ MFCP had the highest value for percentage ash content
$(33.83 \pm 0.52 \%)$ while those fed $20 \%$ MFCSR had the highest value for bone density $(1.15 \pm 0.10 \mathrm{~g} / \mathrm{ml})$.

Bones play an essential role in support of the body mass and protection of internal organs. The control had the highest weight for the left thigh bone which is essential in support of body mass and calcium homeostasis during short or long term calcium deficiency. The bone dry matter percentage is higher in the control and lower in 60\% MFCSR and a decrease in the bone dry matter was observed in MFCP diets as the dietary inclusion level increased. Gonzales and Mendonca (2006) reported that metabolic diseases, including femoral degeneration, can be induced by high density diets during the entire lifetime of poultry birds. On the other hand, Edwards (2000) observed that the incidence of femoral degeneration and other skeletal disorders may be higher when poultry birds are fed high metabolizable energy levels, whereas Mazzuco et al. (2005) did not find

Table 3: Bone Parameters of the left femora of Cockerel Birds Fed Graded Levels of Microbially Fermented Cassava Tuber Wastes

\begin{tabular}{|c|c|c|c|c|c|c|c|}
\hline Parameters & $0 \% \mathrm{CTW}$ & $20 \% \mathrm{MFCP}$ & $40 \% \mathrm{MFCP}$ & $60 \% \mathrm{MFCP}$ & $20 \% \mathrm{MFCSR}$ & $40 \% \mathrm{MFCSR}$ & $60 \%$ MFCSR \\
\hline Left thigh (g) & $98.05 \pm 2.67^{\mathrm{a}}$ & $90.00 \pm 3.39^{\mathrm{a}}$ & $66.00 \pm 3.18^{\mathrm{c}}$ & $73.17 \pm 4.53^{\mathrm{bc}}$ & $79.33 \pm 3.21^{\mathrm{b}}$ & $78.17 \pm 1.76^{\mathrm{b}}$ & $65.50 \pm 3.06^{\mathrm{c}}$ \\
\hline Left femur (g) & $15.83 \pm 1.14^{\mathrm{ab}}$ & $16.17 \pm 0.40^{\mathrm{a}}$ & $13.33 \pm 0.72^{\mathrm{cd}}$ & $15.17 \pm 1.47^{\mathrm{ab}}$ & $16.00 \pm 1.10^{\mathrm{a}}$ & $15.50 \pm 0.56^{\mathrm{ab}}$ & $14.83 \pm 0.79^{c}$ \\
\hline Flesh : Bone ratio & 6.19: 1 & $5.57: 1$ & $4.95: 1$ & $4.82: 1$ & $4.96: 1$ & $5.04: 1$ & $4.42: 1$ \\
\hline Bone moisture(g) & $7.98 \pm 0.22^{\mathrm{ab}}$ & $8.68 \pm 0.12^{\mathrm{a}}$ & $7.50 \pm 0.33^{\mathrm{b}}$ & $8.67 \pm 0.17^{\mathrm{a}}$ & $9.00 \pm 0.34^{\mathrm{a}}$ & $8.18 \pm 0.20^{\mathrm{ab}}$ & $8.83 \pm 0.14^{\mathrm{a}}$ \\
\hline Bone dry matter $(\mathrm{g})$ & $7.85 \pm 0.24^{\mathrm{a}}$ & $7.49 \pm 0.16^{\mathrm{a}}$ & $5.83 \pm 0.11^{\mathrm{c}}$ & $6.50 \pm 0.17^{\mathrm{b}}$ & $7.00 \pm 0.26^{\mathrm{ab}}$ & $7.32 \pm 0.33^{\mathrm{a}}$ & $6.00 \pm 0.27^{\mathrm{bc}}$ \\
\hline BDM (\%) & $49.46 \pm 1.62^{\mathrm{a}}$ & $46.380 \pm 0.62^{\mathrm{ab}}$ & $43.74 \pm 1.20^{\mathrm{bc}}$ & $42.85 \pm 1.97^{\mathrm{bc}}$ & $43.75 \pm 1.47^{\mathrm{bc}}$ & $47.29 \pm 0.77^{\mathrm{ab}}$ & $40.46 \pm 1.24^{\mathrm{c}}$ \\
\hline Bone ash conc. & $0.34 \pm 0.01^{\mathrm{a}}$ & $0.29 \pm 0.03^{\mathrm{b}}$ & $0.35 \pm 0.03^{\mathrm{a}}$ & $0.32 \pm 0.04^{\mathrm{ab}}$ & $0.31 \pm 0.01^{\mathrm{ab}}$ & $0.30 \pm 0.01^{\mathrm{ab}}$ & $0.32 \pm 0.03^{\mathrm{ab}}$ \\
\hline Bone moist (\%) & $50.54 \pm 1.26^{\mathrm{b}}$ & $53.68 \pm 2.63^{\mathrm{ab}}$ & $56.26 \pm 1.84^{\mathrm{a}}$ & $57.15 \pm 2.03^{\mathrm{a}}$ & $56.25 \pm 2.14^{\mathrm{a}}$ & $52.77 \pm 1.87^{\mathrm{ab}}$ & $59.54 \pm 1.92^{\mathrm{a}}$ \\
\hline Bonvol (ml) & $7.62 \pm 0.40^{\mathrm{a}}$ & $7.12 \pm 0.18^{\mathrm{ab}}$ & $5.70 \pm 0.35^{\mathrm{c}}$ & $5.93 \pm 0.55^{\mathrm{bc}}$ & $6.97 \pm 0.77^{\mathrm{abc}}$ & $7.18 \pm 0.38^{\mathrm{ab}}$ & $6.08 \pm 0.30^{\mathrm{bc}}$ \\
\hline Volbonden $(\mathrm{g} / \mathrm{ml})$ & $1.07 \pm 0.02^{\mathrm{ab}}$ & $1.07 \pm 0.03^{\mathrm{ab}}$ & $1.10 \pm 0.05^{\mathrm{ab}}$ & $1.13 \pm 0.06^{\mathrm{a}}$ & $1.15 \pm 0.10^{\mathrm{a}}$ & $1.05 \pm 0.05^{\mathrm{ab}}$ & $1.05 \pm 0.02^{\mathrm{ab}}$ \\
\hline Ash weight (g) & $2.62 \pm 0.05^{\mathrm{a}}$ & $2.03 \pm 0.02^{\mathrm{bc}}$ & $1.97 \pm 0.04^{\mathrm{bc}}$ & $1.92 \pm 0.02^{\mathrm{c}}$ & $2.13 \pm 0.03^{\mathrm{b}}$ & $2.18 \pm 0.05^{\mathrm{b}}$ & $1.95 \pm 0.03^{\mathrm{c}}$ \\
\hline Ash (\%) & $33.37 \pm 1.77^{\mathrm{a}}$ & $27.12 \pm 2.76^{\mathrm{b}}$ & $33.83 \pm 0.52^{\mathrm{a}}$ & $29.52 \pm 1.86^{\mathrm{ab}}$ & $30.40 \pm 1.23^{\mathrm{ab}}$ & $29.83 \pm 1.51^{\mathrm{ab}}$ & $32.57 \pm 2.03^{\mathrm{ab}}$ \\
\hline Bonom (\%) & $66.67 \pm 1.78^{\mathrm{b}}$ & $72.92 \pm 2.76^{\mathrm{a}}$ & $66.18 \pm 0.52^{\mathrm{b}}$ & $70.48 \pm 1.86^{\mathrm{ab}}$ & $69.60 \pm 1.23^{\mathrm{ab}}$ & $70.17 \pm 1.51^{\mathrm{ab}}$ & $67.43 \pm 2.03^{\mathrm{ab}}$ \\
\hline
\end{tabular}


any effect of two different dietary energy levels on the bone mineral density of layers. The results obtained in this experiment could not have been caused by disparity in energy content because all the diets were not only isonitrogenous but also isocaloric. The percentage bone ash was higher in $40 \%$ MFCP, this showed that the diet favored maximal absorption and incorporation of calcium and phosphorous into the bone matrix that in $20 \%$ MFCP diet which recorded lower percentage bone ash content. Park et al. (2003) reported on bone ash percentage of the tibia of laying hens that ranged from 38.84-46.40. The percentage bone ash observed in this trial ranged from 27.12 in the $20 \% \mathrm{MFCP}$ diet to 33.83 in the $40 \%$ MFCP diet. The lower bone ash percentage recorded in this experiment may be due to the type of birds (cockerels versus layers), type of bone (femur versus tibia) and the age of the birds. Cockerels at 17 weeks have not completed normal calcification and mineralization of their bone especially at the epiphyses and this could account for a lower bone ash percentage. The ash weight of the bones compared with those obtained by Kim et al. (2007) on the use of alfalfa-based diets in the induction of forced moulting in layers.

The percentage of bone organic matter was however higher in 20\% MFCP but lower in $40 \%$ MFCP. This implied a higher level of protein and fat in the bones of birds fed $20 \%$ MFCP diet. It was observed that the higher the percentage ash, the lower the bone organic matter and vice versa, an inverse relationship between the percentage bone ash and percentage bone organic matter was thus established.

The values of the plasma and whole blood viscosities for cockerel finishers fed dietary inclusion of cassava tuber waste are presented in Table 4. The Table 4 showed that the whole blood viscosity was not significantly influenced $(p>0.05)$ by the dietary treatments. The plasma viscosity varied significantly among the dietary treatments. It was lowest in $\mathrm{T} 1(1.02 \mathrm{cS})$ and highest in $\mathrm{T} 2(1.14 \mathrm{cS})$. However, the viscosity of the whole blood and that of blood plasma decreased as the inclusion rate of the cassava tuber waste increased in all the MFCSR diets i.e. from T5-T7 while those of the MFCP did not decrease in an inclusion rate dependent manner.

Previous experiments on the blood viscosity of cattle, sheep, rabbit and mouse have also shown variation in viscosity values of the blood of these animals (Windberger et al., 1994).

The values of the plasma viscosity were lower when compared with the viscosity of the whole blood because the formed elements (Haematocrit) that would have made it more viscous had been removed by centrifugation. Also the plasma viscosity showed a considerable decrease from T5T7. Generally, species with low plasma viscosity such as rabbit and mouse might elicit lower endothelial shear stress than animals with high plasma viscosity such as

Table 4: Blood viscosities (in centistokes) of cockerels fed graded levels of microbially fermented cassava tuber waste (MFCTW) diets

\begin{tabular}{|c|c|c|c|c|c|c|c|}
\hline Parameters & O\% CTW & $20 \% \mathrm{MFCP}$ & $40 \% \mathrm{MFCP}$ & $60 \% \mathrm{MFCP}$ & $20 \% \mathrm{MFCSR}$ & $40 \% \mathrm{MFCSR}$ & $60 \% \mathrm{MFCSR}$ \\
\hline $\begin{array}{l}\text { Whole } \\
\text { blood }\end{array}$ & $2.55 \pm 0.18$ & $2.82 \pm 0.24$ & $2.70 \pm 0.26$ & $2.45 \pm 0.16$ & $2.61 \pm 0.04$ & $2.44 \pm 0.13$ & $2.36 \pm 0.10$ \\
\hline Plasma & $1.02 \pm 0.03^{\mathrm{d}}$ & $1.14 \pm 0.02^{\mathrm{a}}$ & $1.10 \pm 0.02^{\mathrm{abc}}$ & $1.13 \pm 0.01^{\mathrm{ab}}$ & $1.12 \pm 0.01^{\mathrm{ab}}$ & $1.08 \pm 0.01^{\mathrm{bc}}$ & $1.06 \pm 0.01^{\mathrm{cd}}$ \\
\hline
\end{tabular}


cattle (Pfafferott et al., 1999). The decrease in plasma viscosity with increase in dietary levels of these two MFCTWs could thus help guide against the risk of acute coronary syndrome and intermittent claudication in animal and human subjects fed with such fermented cassava products. One major factor that can cause decrease in blood viscosity is anaemia, but since all the MFCTW diets had superior or comparable viscosities with the control diets, such decrease in blood viscosity with dietary inclusion of the MFCTWs could not have been caused by a state of anaemia in the birds.

Elevated whole blood and plasma viscosity may also play an important and significant role in the development of diabetic retinopathy (Turczyński et al., 2003) - a condition which the utilization of CTWs fermented under this protocol could help guide against.

\section{Conclusion}

The present study showed that the inclusion of these wastes did not show any apparent deleterious effect on bone quality of cockerels. The utilization of these biotechnologically enhanced wastes in the diets of cockerel finishers would also lead to a decrease in whole blood and plasma viscosities at higher levels of inclusion (40\% and 60\%) and could help ameliorate the conditions of hyperviscosity in livestock species such as cockerel birds and possibly cattle. Viscosities of the blood of livestock fed inclusion of fermented cassava waste products should therefore be determined as part of routine haematological screening so as to get a true picture of the erythrocyte sedimentation rate whose true values could be confounded by the viscosity of either the plasma or whole blood.

From the results obtained in this experiment, the dietary inclusion of microbially fermented cassava peel (MFCP) and microbially fermented cassava starch residue (MFCSR) up to $60 \%$ has no deleterious effect on the whole blood and plasma viscosity of cockerels.

\section{References}

Ani, A.O and Okorie, A.U. 2009. The nutritive value of dehulled and cooked castor oil bean Ricinus communis L meal to broiler finishers. Proc. $27^{\text {th }}$ Ann Conf., NSAP, March 17-21. FUT, Akure pp 141-143.

Aro, S. O., Agbede, J. O., Dairo, O. O., Ogunshote, E. and Aletor, V. A. 2012. Evaluation of fermented cassava tuber wastes in broiler chickens feeding. Archiva Zootechnica 15(3): 49-60.

Aro, S.O. 2010. Growth and reproductive response of swine fed fermented cassava tuber wastes. Ph.D Thesis. University of Ibadan, Nigeria. pp 1176.

Association of Official Analytical Chemist (AOAC). 1994. Official Method of Analysis (13 ${ }^{\text {th }}$ edition) Washington D.C USA.

Edwards Jr., H. M. 2000. Nutrition and skeletal problems in poultry. Poultry Science, 79(7): 1018-1023.

Chan, M. M., Rucker, R. B. and Riggins, A. S. 1976. Effects of fluoride and ethane-1-hydroxy-Ll diphosphonate on bone metabolism in the growing chick.J. Nutr. 106: 802-811.

F.A.O, 1986. Africa agriculture in the next 25 years. Food and Agriculture Organization, Rome, Italy.

Faniyi. G.F. and Ologbhobo, A.D. 1999. Effect of replacing brewer dried grain with rye and urea treated cowpea and sorghum seed husks in broiler diet. Trop. Anim. Prod. Invest. 2:69-82. 
Effect of microbially fermented cassava tuber wastes on blood viscosity and bone quality of finisher cockerels

Gonzáles, E. and Mendoça Jr, C. X. 2006. Problemas locomotors em frangos de corte. VII Simpósio Brasil Sul de Avicultura. Chapecó, SC - Brasil. Anais. Pp.79-94.

Kim, W. K.., Donalson, L. M., Bloomfield, S. A., Hogan, H. A., Kubena, L. F., Nisbet, D. J. and Ricke, S. C. 2007. Molt performance and bone density of cortical, medullary, and cancellous bone in laying hens during feed restriction or alfalfa-based feed molt. Poultry Science 86:1821-1830

Mazzuco, H., Mc Murtry, J. P., Kuo, A.Y. and Hester, P. 2005. The effect of preand postmolt diets high in $\mathrm{n}-3$ fatty acids and molt programs on skeletal integrity and insulin-like growth factor- I of white leghorns. Poultry Science, 84:1735-49.

NRC, 1994. Nutrient Requirements of Poultry (9th ed.). National Research Council, National Academy Press, Washington D.C., USA.

Oluremi, O.I.A, Mou, P. M and Adenkola, A. Y. 2008. Effect of fermentation of sweet orange (Citrus sinensis) fruit peel on its maize replacement value in broiler diets. Livestock Research for Rural Development. Volume 20, Article \#20. Retrieved March 4, 2014, from http://www.lrrd.org/lrrd20/2/olur200 20.htm

Park, S. Y., Birkhold, S. G., Kubena, L. F., Nisbet, D. J., and Ricke, S. C. 2003. Effect of storage condition on bone breaking strength and bone ash in laying hens at different stages in production cycles. Poultry Science, 82:1688-1691

Pfafferott, C., Moessmer, G., Ehrly, A.M. and Bauersachs, R.M. 1999. Involvement of erythrocyte aggregation and erythrocyte resistance to flow in acute coronary syndromes. Clin. Haemorheol. Microcirc. 21:35-43.

Potença, A., Murakami, A. E., Fernandes, J. I. M., Matsushita, M. and Nakagawa, E. L. 2008. Performance, abdominal fat deposition and bone characteristics of broilers fed diets containing different lipid sources. Revista Brasileira de Ciência Avícola ISSN 1516-635X

Rosencranz, R. and Bogen, S. A. 2006. Clinical laboratory measurement of serum, plasma, and blood viscosity. American Journal of Clinical Pathology. 125(Suppl 1):S78-S86

Shahnazari, M., Martin, B. R., Legette, L. L., Lachcik, P. J., Welch, J. and Weaver, C. M. (2009). Diet Calcium Level but Not Calcium Supplement Particle Size Affects Bone Density and Mechanical Properties in Ovariectomized Rats. J. Nutr. 139: 1308-1314,

SPSS Statistical Package for Social Scientists (2008). SPSS bass 17.0 user's guide, copyright (C) 2008. SPSS Inc., 233 South Wacker Drive, 11th Floor.Chicago.1160606-6412.

Tewe. O.O., Aderemi, F.A. and Oguntimehin, G.B. (1994). Processing and utilization of cassava roots and leaves in diets of layers. Paper presented at the $10^{\text {th }}$ triennial symposium of the ISTRC Bahia.

Turczyński, B.1., Michalska-Małecka, K., Słowińska, L., Szczesny, S. and Romaniuk, W. 2003. Correlations between the severity of retinopathy in diabetic patients and whole blood and plasma viscosity. Clinical Hemorheology and Microcirculation. 29(2):129-137.

Windberger, U., Ribitsch V., Resch, K.L. 
and Losert, U. 1994. The viscoelasticity of blood and plasma in pig, horse, dog, ox and sheep. J. Exp. Anim. Sci. 36: 89-95.
Zhang, B. and Coon, C .N. 1997. The relationship of various tibia bone measurements in hens. Poultry Science, 76:1698-701.

Received: $7^{\text {th }}$ February, 2013

Accepted: 12 ${ }^{\text {th }}$ June, 2014 